\title{
EXPLORING CRYPTO-CURRENCY OWNERSHIP IN THE CONTEXT OF TECHNOLOGY ACCEPTANCE MODEL AND TECHNOLOGY ADOPTER CATEGORIES: COIN-OPTIMISTICS, OBSERVERS AND COIN-SCEPTICS
}

\section{SOSYAL BILIMLER DERGISI}

ANKARA UNIVERSITY JOURNAL OF SOCIAL SCIENCES

10.33537/sobild.2020.11.2.5

\section{Makale Bilgisi}

Gönderildiği tarih: Kabul edildiği tarih: Yayinlanma tarihi:

13.02.2020 08.06 .2020 30.06 .2020

\section{Article Info}

Date submitted: Date accepted:

Date published:
13.02.2020

08.06 .2020

30.06 .2020

\section{TEKNOLOJI KABUL MODELİ VE TEKNOLOJI BENIMMSEME KATEGORILLERI BAĞLAMINDA KRIPTO PARA BIRIMII SAHIPLIǴİNI KESSFETMEK: KOIN-İYIMSERLER, GÖZLEMCİLER VE KOIN-ŞÜPHECILLR}

\section{Cansu ÖKSÜZ KARADEMİR}

İstanbul Üniversitesi, Sosyal Bilimler Enstitüsü, Radyo Televizyon ve Sinema Anabilim Dalı, doktora öğrencisi, cansuoksuz@hotmail.com

\section{Oğuz KUŞ}

Araștırma Görevlisi Doktor, İstanbul Üniversitesi, İletișim Fakültesi, Halkla İişkiler ve Tanitım Bölümü, oguz.kus@istanbul.edu.tr

\section{Keywords}

Cryptocurrency; Technology acceptance model; Technology adopter categorization; Cryptocurrency acceptance; Cryptocurrency adopter categorization

\section{Anahtar sözcükler}

Kripto para; Teknoloji kabul modeli; Teknoloji benimseme kategorizasyonu; Kripto para kabulü; Kripto para benimseme kategorizasyonu

\section{Abstract}

This study aims to understand the cryptocurrency ownership tendencies in Turkey by using technology acceptance model, and technology adopter categorization. Data collected from 407 participants was analysed with data mining and descriptive statistical techniques. Performance expectancy and facilitating conditions are the most significant variants that affect the cryptocurrency ownership decision. Three different cryptocurrency adopter categories were determined. Coin-optimistics approach cryptocurrencies as a means to achieve their objectives. They are pioneers who gain and diffuse information on cryptocurrencies. Observers act based on the information they obtain on cryptocurrencies. Their anxiety and knowledge level affect their decision. Coinsceptics are not cryptocurrency owners because of anxiety about suffering economic loss and availability of more traditional alternatives.
$\ddot{O} z_{z}$

Bu çalışmada, teknoloji kabul modeli ve teknoloji benimseme kategorizasyonu kullanılarak Türkiye'de kripto para birimi sahiplik eğilimlerinin anlaşılması amaçlanmıştır. 407 katılımcıdan toplanan veriler, veri madenciliği ve tanımlayıcı istatistiksel teknikler ile analiz edilmiştir. Performans beklentisi ve kolaylaştırıcı koşullar, kripto para birimi sahiplik kararin etkileyen en önemli değişkenlerdir. Üç farklı kripto para benimseme kategorisi belirlenmiştir. Koin-iyimserler, kripto para birimlerine hedeflerine ulaşmak için bir araç olarak yaklaşmaktadır. Kripto para birimleri hakkında bilgi edinen ve dağıtan öncülerdir. Gözlemciler, kripto para birimlerinde elde ettikleri bilgilere dayanarak hareket ederler. Kaygi ve bilgi düzeyi, kararlarını etkilemektedir. Koin-şüpheciler ise ekonomik kayip ve daha geleneksel alternatiflerin kullanılabilirliği konusunda endişe nedeniyle kripto para birimi sahipleri değildir. 


\section{Introduction}

Cryptocurrencies, which bring technology and economy together on a common ground, are integrated to different segments of daily life day by day. This integration causes cryptocurrencies to take a wider part in the economic and academic agenda of our time. This study aims to find out which parameters are more effective in the cryptocurrency ownership decisions of individuals, and develop cryptocurrency adopter categorizations.

Within the scope of the study, historical background of cryptocurrencies starting from cryptography, their operating logic and mentality were addressed in order to provide a basis about cryptocurrencies. Explanations were given/provided about Bitcoin, which has the highest volume in the cryptocurrency market, alt-coins, which emerged in the market after Bitcoin, and how they are used in the market.

After conceptual ground with regard to cryptocurrencies was established, theoretical ground was established to find out the factors, which affect cryptocurrency ownership of individuals. Technology acceptance model and technology adopter categorization perspective were used for understanding factors, which affect the cryptocurrency ownership of individuals. Technology acceptance model variants, namely performance expectancy, effort expectancy, social influence, facilitating conditions and anxiety, were considered by individuals in terms of cryptocurrency ownership. On the other hand, a connection was established between technology adopter categorization, technology adaptation pattern and cryptocurrency ownership. For the research, data was collected with the questionnaire, which was carried out in Turkey between the dates 15.04.2019 - 22.05.2019 with the participation of 407 persons. Decision tree algorithm and descriptive statistical techniques were used to analyse 385 questionnaires, which were included to the research.

With this aspect, the study has an original and pioneering characteristic in that it sheds light on the cryptocurrency ownership tendencies of users in Turkey. On the other hand, since it establishes a connection between technology acceptance model and technology adopter categorisations, the study extends the scope of both approaches. Finally, the study contributes to the literature by providing cryptocurrency adopter categorization as a result of the study, and provides a basis for future studies on cryptocurrencies.

Historical Background, Understanding and Function of Cryptocurrencies

In the second machine age, when the actual promise is to unveil the creativity and imagination of humans (Brynjolfsson \& McAffee, 2014, p. 294), emergence of applicable cryptocurrency is closely related with the developments in cryptography (Antonopoulos, 2015, p. 2). Because after cryptography became widely applicable and understood by more people, several researchers started to use cryptography to create digital currencies (2015, p. 3). According to Swan (2015), a blockchain is a chain of transaction records, usually referred to as blocks, which grows autonomously, and all the records are linked together to form a chain, and secured through cryptographic techniques. In other words, cryptocurrencies, which use encryption technique and encompass decentralized digital currencies (Gandal \& Halaburda 2014, p. 2), is a new method provided by monetary and payment systems by making use of technological developments. Blockchains allow us to have a distributed peer-to-peer network where non-trusting members can verifiably interact with each other without the need for a trusted authority (Christidis \& Devetsikiotis, 2016). Thanks to this, a monetary system, which is managed completely on electronic medium without needing any coin or paper money, has become possible. For cryptocurrency, which cannot make use of esoteric inks or holographic strips, while cryptography forms a basis for relying on the legitimacy of disclosing the value of a user, cryptographic digital signatures allow the user to sign a digital asset or transaction that verifies the ownership of this asset. In this context, it is of particular importance to mention Nakamoto and Bitcoin, which was created by him, to understand the concept and functioning of cryptocurrencies.

The technical system used as the infrastructure of electronic coins, which consists of a chain of digital signatures (Nakamoto, 2008, p. 2), was created by a person or group named Satoshi Nakamoto. When the article titled "Bitcoin: A Peer-to-Peer Electronic Cash System" was published, previous inventions such as Bmoney and HashCash were combined and an electronic cash system, which does not depend on a central authority, and is not completely centralized was invented in 2008 for regulating the currency, or conducting and approving the transactions. This Bitcoin network, which is based on a reference application published by Nakamoto, started to be used in 2009 since it was revised by many programmers (Antonopoulos, 2015, p. 3). From then on, the virtual money called bitcoin was put in circulation by private persons without the authorisation of central bank or any other public enterprise.

Developed as an open-source software, bitcoin protocol stack can be operated with a wide range of devices including laptop and smartphones, which render the technology easily accessible. While the fact that it is inimitable and produced in accordance with certain rules allows the currency to have important characteristics, namely, acceptability, stability of value, portability, longevity, uniformity, what makes it valuable and valid is directly proportional to its quality of being a medium of exchange and its paying ability. Bitcoins can be purchased, sold in custom currencies, and exchanged for other currencies. In a sense, bitcoin is a perfect currency for internet since it is fast, reliable and infinite (Antonopoluous, 2015, p. 1).

While transferring online payments from one financial institution to another without being subject to the authorisation of a financial body is permitted by means of the system and thanks to a peer-to-peer electronic money version, during the exchange of money, the owner of the money sends it to the next party, approves the transaction summary and public key of the next owner with his/her own digital signature, and attaches this signature to the end of the money (Nakamoto, 2008, p. 1). It is critical to note that the validation process by every one-hop node in the network makes it literally impossible for invalid transactions to be broadcasted. This then reaffirms the issues of security and authenticity of the transactions (Allam, 2018, p. 
143). While the economy created with hardware mining without needing intermediaries or any central distribution system, cryptocurrencies based on computer operating system and cryptographic combination, are based on a distributed trust mechanism called blockchain, which is considered as a reliable method for keeping track of the transaction (Schwab, 2018, p. 166) users may directly and anonymously communicate with each other through this system without the intervention of any third party (Plassaras, 2013, p. 379).

Blockchain confers to digital identity a potentially revolutionary decentralization character (Pilkington, 2015). Bitcoin, which has a decentralised peer-to-peer network, a public transaction book (blockchain), decentralised mathematical and deterministic money issuance (distributed mining) and a decentralised transaction verification system (process script), brings along several benefits and risks just like all innovations. While it provides the users the freedom of payment, commercial advantages, user control and a platform for further innovations; its internally changing nature and market volatility, aspects such as the facilitation of criminal activities and economic risks may pose potential threats (Chuen, 2015, p. 23). European Commission (2015) takes cryptocurrencies into account in addition to current technologies such as artificial intelligence for the implementation of new technologies to banking sector, The Financial Action Task Force (2014, p. 3) and European Commission (2015, p. 8) draw attention to the fact that funding terrorism or laundering money has become possible since cryptocurrencies can now be converted into real currencies. (European Commission, 2015; FATF, 2014).

Also, based on the money matrix set forth by European Central Bank, cryptocurrencies in digital format can theoretically not be presented with any physical material (Plassaras, 2013, p. 379). The blockchain, which prevents the control of digital identity by a central institution, can only be controlled by the individual itself (Pilkington, 2015). In this context, users need a medium to rely on for positive feedbacks about the validity of transactions made due to the concerns over possible losses resulting from the absence of a physical reality. However, Nakamoto (2008, p. 1) suggests that what is needed is direct transactions between only two willing parties without needing others rather than the trust.

Currently, Bitcoin and cryptocurrencies which include alt-coins, are gradually more integrated to the daily life as investment or use instruments. According to Gandal and Halaburda (2014), who lay emphasis on the fact the network effects play a significant role in the context of money competition and the competition between stock markets, a product or a service acquires value when the number of its users increases. Therefore, a currency will become more functional when it is adopted by more people. In other words, the exchange is more fluid when there is more buyers and sellers (2014, p. 2). At this point, the more a currency is known, the easier it will be for the currency to attract new users and similarly, if there is a bigger change in question, it will provide attractive options for new buyers and sellers. As bitcoin and alt-coins, use areas of which increase with each new day, gain more importance in the economy, the need to make changes and arrangements about virtual coins used directly on the network between the parties without any intermediaries, on both national and international level.

On the other hand, it is also important to address discussions, explanation and some of the legislations with regard to the legal status of cryptocurrencies. For instance, in the State of Wyoming, cryptocurrencies are considered in the status of digital asset and accepted as property (State of Wyoming, 2019). European Central Bank $(2018,2015)$ prepares reports for determining the effect, usage areas of cryptocurrencies and reactions of different member states to the use of cryptocurrencies. In Turkey, the public has been informed and warned about various problems such as the impossibility of controlling and supervising cryptocurrencies, market volatility, information theft or fraud, but no bans have been imposed. (Banking Regulation and Supervision Agency, 2013 , 2013). In this case, the fact that cryptocurrencies, which are put under any prohibition despite not being recognised as legal, lack any legal status makes any Bitcoin accounting or taxation impossible.

When the summary statistics of the final papers on Bitcoin are analyzed, it is seen that the finance sector constitutes the main subject, followed by records management, supply chain, entertainment and communication, state government and private transportation respectively (Schlegel, Zavolokina \& Schwabe, 2018).

Finally, it is vital to provide information on cryptocurrency studies and market in Turkey since the research aims to understand important factors that play a role in the cryptocurrency ownership of individuals living in Turkey. It is observed that different cryptocurrency stock markets centred in Turkey have significant volumes. According to CoinMarketCap data, three cryptocurrency stock markets centred in Turkey are ranked among the first hundred stock markets in terms of transaction volume. On the other hand, several studies were conducted in Turkey for exploring the role of cryptocurrencies in different contexts. For instance, studies which were conducted by Gültekin \& Bulut (2016); Gültekin (2017) and Karaoğlan, Arar \& Bilgin (2018) focused on newly emerged industries related to Bitcoin and usage of cryptocurrencies in industry; Kamac1 \& Özden (2019) contributed to a discussion which likens Bitcoin to Tulipmania; various studies exist which approach cryptocurrencies in accounting and taxation context (Şahin, 2019; Temelli, 2019; Dizkırıc1 \& Gökgöz, 2019).

Technology Acceptance Model and Technology Adopter Categorization

Process of digital transformation, which is also called "The Second Machine Age" gains an absolute momentum with the invention of computers, development of internet, popularization of personal computers and mobile devices (Brynjolfsson \& McAffee, 2014). Technological developments, which render the concepts of time and space transparent in a process that is observed to be based on information, interaction, access and cooperation rather than physical and industry-oriented production, has made interaction between systems possible virtually anytime and anywhere without limiting itself to individuals and institutions. New situations, which introduced a 
technology based change in social life, creates a digital culture different from customary habits, therefore transform classical life styles (Wallerstein, 1999). On the other hand, the global network created by ongoing developments on a global scale oblige individuals, institutions and systems to take part in innovations in a synchronised manner and adopt themselves with such developments. It is observed that digital transformation, which, in respect of technological access, gained a significant place in several areas including education, health, finance and communication, has a remarkable effect on the current social and economic status.

In this case, only through a comprehensive and global understanding about how technology changes our lives and the lives of next generations, and how our age has been reshaped in economic, social, cultural and human context can we construct a collective future that reflects common goals and values (Schwab, 2018, p. 117125). When the development of information society, the speed of digitalization especially in the last 50 years, and technological advantages of this age unlike those of previous eras are considered, it is observed that this process surrounds people in a spiral and pushes them to an inevitable transformation and a tendency towards evolution. In this context, technology is important for the sustainable growth of a country starting from the individual, and achieving social welfare. However, whether the aspects, scale and effect of these developments turn out to be positive or negative will depend completely on the attitudes and strategies of individuals, institutions and economies, through which they react to the process of transformation (Brynjolfsson $\&$ McAffee, 2014). While the capability of adopting to new technologies, which has a vital role for 21 st century, is connected to the sustainable and systematizable character of innovative solutions, it is possible to define the learning and applicability process of technology as individual technology acceptance process. As a condition that must be interiorized due to these cultural and social changes, technology introduces remarkable changes between the individuals of the current age in the context of attitudes towards the adoption of technology. In this regard, Rogers (1983) and Moore (1991) categorized the profiles of technology adoption groups in the table below (see Table 1).

In the categorization, five sub-segments, namely innovative technology enthusiasts (innovators), an early adopting minority (early adopters), early adopting majority (early majority), late adopting majority (late majority) and the last adopters (laggards), were determined.

\begin{tabular}{|c|c|c|c|}
\hline Categorisation & $\begin{array}{l}\text { Attitude Towards } \\
\text { Technology }\end{array}$ & Behavioural Pattern & $\begin{array}{l}\text { Adaptation Process/Decision } \\
\text { Process }\end{array}$ \\
\hline Innovators & $\begin{array}{l}\text { Not need oriented, } \\
\text { primary objective is to } \\
\text { have it. }\end{array}$ & $\begin{array}{l}\text { Follows the developments } \\
\text { closely. Their feedbacks } \\
\text { are important. }\end{array}$ & $\begin{array}{l}\text { They are the first to tend towards } \\
\text { the innovation. }\end{array}$ \\
\hline Early Adopters & $\begin{array}{l}\text { They receive technology } \\
\text { not for trying, but for the } \\
\text { purpose of using it. }\end{array}$ & $\begin{array}{l}\text { They assume the role of } \\
\text { decreasing ambiguities } \\
\text { about new ideas, and } \\
\text { transmitting the } \\
\text { subjective evaluation of } \\
\text { the innovation by means } \\
\text { of interpersonal networks. }\end{array}$ & $\begin{array}{l}\text { Early adopters, which are in the } \\
\text { position of role models for many } \\
\text { members of the social system, are, } \\
\text { after the innovators, the earliest } \\
\text { group to have access to } \\
\text { technology. }\end{array}$ \\
\hline Early Majority & $\begin{array}{l}\text { They only prefer } \\
\text { approved, generally } \\
\text { accepted products } \\
\text { without taking risks. }\end{array}$ & $\begin{array}{l}\text { With their position in the } \\
\text { table, they establish } \\
\text { connection between } \\
\text { networks. They take care } \\
\text { not to be the last person } \\
\text { to put aside the old rather } \\
\text { than being the first to try } \\
\text { the new. }\end{array}$ & $\begin{array}{l}\text { They prefer taking time to ponder } \\
\text { over an idea before accepting it, } \\
\text { and their innovation decision time } \\
\text { is longer than innovators and } \\
\text { early adopters. }\end{array}$ \\
\hline Late Majority & $\begin{array}{l}\text { Late majority, who have } \\
\text { a sceptic approach to } \\
\text { innovations, avoid using } \\
\text { the technology directly. } \\
\text { They also may have } \\
\text { difficulty in using the } \\
\text { technology. }\end{array}$ & $\begin{array}{l}\text { They are not in search of } \\
\text { new until they have } \\
\text { problems in their current } \\
\text { ownership. }\end{array}$ & $\begin{array}{l}\text { For late adopting majority, who } \\
\text { enter in the acceptance process } \\
\text { right after the average members of } \\
\text { the social system, technological } \\
\text { adaptation is both an economic } \\
\text { requirement and a response to the } \\
\text { increasing network pressures. } \\
\text { They cannot adopt to the new } \\
\text { technology until most people in } \\
\text { their social system do this. }\end{array}$ \\
\hline
\end{tabular}




\begin{tabular}{|l|l|l|l|}
\hline Laggards & $\begin{array}{l}\text { Previous uses have } \\
\text { become habits for } \\
\text { laggards, who are } \\
\text { reluctant to adopt } \\
\text { innovations and act with } \\
\text { traditional perspective. } \\
\text { They are sceptic towards } \\
\text { the new. Also, their } \\
\text { connections with the } \\
\text { past prevent the } \\
\text { tendency towards the } \\
\text { new. }\end{array}$ & $\begin{array}{l}\text { They tend towards a new } \\
\text { product only when there } \\
\text { is no alternative to it. } \\
\text { Their resistance to } \\
\text { innovations may stem } \\
\text { from the fear of the } \\
\text { unknown. }\end{array}$ & $\begin{array}{l}\text { While their traditional orientations } \\
\text { slow down innovation decision } \\
\text { process, they focus more on the } \\
\text { past compared to other social } \\
\text { categories. }\end{array}$ \\
\hline
\end{tabular}

Table 1: Technology Adopter Categorization presented by Rogers (1983) and Moore (1991)

With regard to the acceptance of technological innovations, Rogers (1983) and Moore (1991) categorised groups, which adopt technology with different speed and behaviour patterns. Although this categorization provides hints concerning the acceptance of a technological development, it is also necessary to read this phenomena with technology acceptance model, which is repeatedly tested with different versions. Davis (1989), who developed the first version of Technology Acceptance Model (TAM) drew attention to the importance of the concepts 'perceived usefulness' and 'perceived ease of use' concerning the acceptance of a technological innovation. In this regard, while perceived usefulness is defined as "the degree to which a person believes that using a particular system would enhance his/her job performance", perceived ease of use is defined as "the degree to which a person believes that using a particular system would be free of effort" (Davis, 1989; Davis, Bagozzi \& Warshaw, 1989). Davis et. al., (1989) also underline the fact that an individual's performance of exhibiting a specific behaviour is determined by that person's tendency to exhibit that behaviour (behavioural intention) by making use of theory of reasoned action.

As seen in researches carried out in different contexts, it was observed that perceived usefulness and perceived ease of use, which are among the principal components of TAM, have an effect in the context of technology acceptance. In the following years of the development of technology acceptance model, it was used in significant studies which aim to understand influential factors in usage of basic technologies such as computers (Davis, Bagozzi \& Warshaw, 1992; Igbaria, Iivari \& Maragahh, 1995; Igbaria, Zinatelli, Crag \& Cavaye, 1997; Jackson, Chow \& Leitch, 2007), softwares (Morris \& Dillon, 1997) and information technology (Adams, Nelson $\&$ Todd, 1992). Technology acceptance model has been applied to various studies in order to identify influential factors in the acceptance of current technologies such as mobile instant messaging (Oghuma, Libaque-Saenz, Wong \& Chang 2016); mobile payment systems (LiébanaCabanillas, Muñoz-Leiva \& Sánchez-Fernández, 2017), smart home services (Park, Kim, Kim \& Kwon, 2018), driverless vehicles (Nordhoff, Winter, Kyriakidis, Arem \& Happee, 2018) travel applications (Choi, Wang \& Sparks, 2019) and new media entertainment (Liu, Liu \& Tu, 2019).

Venkatesh and Davis (2000) developed TAM2 by using TAM as a basis. Effects of social factors on the acceptance of a new technology was tested within the framework of TAM2. Venkatesh and Davis (2000), who drew on the ideas of Fishbein and Ajzen, defined subjective norm as "person's perception that most people who are important to him think he should or should not perform the behaviour in question" and found that it has an effect on usage intention.

TAM2 model was used in different studies, which explain the role of social influence factor on the technology adaptation. For instance, Wu, Wen \& Huang (2011, p. 145) stated that users' acceptance of Web 2.0 websites is mainly influenced by beliefs of people important to the users; According to Qin, Kim, Hsu \& Tan (2011), subjective norm and critical mass, which were classified as two variables of social influence within the framework of their study, significantly affect perceived usefulness. Ingham, Cadieux \& Berrada (2015) found that "although the direct impact of social influence on the intention to buy online is relatively modest, its impact on the attitude toward purchasing products and services online is more significant.". Patel \& Patel (2018), underlined the fact that intention to use internet banking is affected by social influence positively; Shao \& Kwon (2019), who used TAM \& TAM2 in terms of a study focuses nuanced social feedback system, suggest that social influence mattered when constructing users' perceptions toward the usefulness of the system however it did not directly increase their use intention.

TAM reached to its final form with Unified Theory of Acceptance and Use of Technology (UTAUT) (Venkatesh, Morris, Davis \& Davis, 2003) and Unified Theory of Acceptance and Use of Technology 2 (UTAUT 2) (Venkatesh, Thong \& Xu, 2013). Venkatesh et. al. (2003) developed new and unifying concepts called performance expectancy, effort expectancy and social influence, which incorporate the concepts of perceived usefulness, perceived ease of use and subjective norm, main components of previous models in the context of UTAUT. The concept of performance expectancy was defined as "the degree to which an individual believes that using the system will help him or her to attain gains in job performance"; the concept of effort expectancy was defined as "the degree of ease associated with the use of the system" and the concept of social influence was defined as "the degree to which an individual perceives that important others believe he or she should use the new system" (Venkatesh et al., 2003, p. 447-451).

In addition to the previous versions of the model, UTAUT includes two parameters called facilitating conditions and anxiety, which are important for the study. Venkatesh et al., (2003, p. 453) define facilitating conditions parameter as "the degree to which an individual believes that an organizational and technical 
infrastructure exists to support use of the system". It is understood that the term anxiety referred in UTAUT originates from computer anxiety. Venkatesh (2000, p. 349) quotes the definition of Simonson et. al. and defines the term computer anxiety as "individual's apprehension, or even fear, when she/he is faced with the possibility of using computers". Although Venkatesh et. al., (2003) underline that anxiety parameter, which they mention within the framework of UTAUT model, does not have a direct effect on tendency to use, the importance of this parameter must be emphasized within the scope of this study, which addresses a development like cryptocurrency that brings technology and economy together. Performance expectancy, effort expectancy, social influence, facilitating conditions and behavioural intention parameters used in UTAUT model were included to UTAUT 2 developed by Venkatesh et. al., (2013) and parameters, which measure the effect of individual characteristics such as hedonic motivation, habit and use, on technology acceptance, were added to this version.

Like the previous versions of the model, UTAUT and UTAUT 2 were also used in studies carried out in various fields in order to explain technology acceptance behaviour. It is possible to observe usage of UTAUT in current studies. Lawson-Body, Willoughby, Lawson-Body $\&$ Tamandja, (2018) found that perceived usefulness has a significant impact on attitude toward e-books. Cao \& Niu (2019), Alipay ${ }^{1}$ emphasized the fact that performance expectancy, one of the parameters presented in UTAUT, has an important role in terms of user adaption. Yang, Feng \& MacLeod (2018) found that effort expectancy and social influence, which are among the components of UTAUT, have an effect on cloud classroom acceptance of students. Naranjo-Zolotov, Oliveira \& Casteleyn (2019), who conducted a study in order to identify effective parameters in citizens' e-participation, suggested that performance expectancy and facilitating conditions were the strongest predictors of intention to use eparticipation.

Like UTAUT, the use of UTAUT 2 can be observed in current researches. Tavares (2017) used UTAUT2 in order to define parameters which affect adoption of electronic health record portals; Halassi, Semeijn \& Kiratli (2019) applied it in order to determine main determinants of intention to use and consumer acceptance in threedimensional printing technologies; Herrero, Martín \& Garcia-de Los Salmones, (2017) conducted a questionnaire which contains sample of 537 tourists and identified drivers of users' intentions to use social network sites to publish content; Morosan \& DeFranco (2016) found that performance expectancy is the key predictor of intentions for using NFC mobile payments in hotels.

Suggested by Davis and developed over the course of time, technology acceptance model is an effective and sufficient theory, which is institutionalized for explaining the components that play a role in the acceptance and use of new technologies as noted in the theoretical framework presented above. Arbaugh (2010) underlines that "Several multidisciplinary studies have used the TAM as a grounding framework, either in its original form
(Davis, 1989) or in the extended model (Venkatesh \& Davis, 2000)." On the other hand, innovation adopter categorization of Rogers (1983) is important for defining technology adoption profile and speed of applicants. The fact that the theory has been used in many studies since it was first shared with the academic audience until now and examples shared in the context of the study validate this claim. In this sense, it would not be wrong to argue that technology acceptance model, and extended models developed based on this model can provide a multidimensional insight for explaining the use of cryptocurrency.

Researches, which address the economic platforms of individuals and how they use cryptocurrencies based on TAM model also confirm the validity of this argument. As an example, Abroud, Choong, Muthaiyah and Fie (2013) found a relationship between stock market behaviour on the internet, and two parameters of TAM, namely, perceived usefulness and ease of use. Studying the mobile banking services acceptance behaviours of rural community in Zimbabwe, Chitungo and Munongo (2013) found that perceived usefulness, perceived ease of use and social norms, which are parameters of TAM, have an influence on mobile banking services acceptance behaviour. With this aspect, cryptocurrencies, which become an investment and exchange instrument, and which are also founded on a technological ground, can be analysed from the perspective of TAM.

Folkinshteyn and Lennon (2017) suggest the following arguments about the use of TAM in cryptocurrency researches.

"Our analysis and discussion of Bitcoin and blockchain in the context of the TAM have important implications for practitioners and researchers alike [...] For both developers and end users, Bitcoin the currency has a number of significant positive factors in PEU and $\mathrm{PU}$, stemming from its free open source nature, putting the user in control, and increased efficiency of transactions."

On the other hand, Arias-Oliva, Pelegrin-Borondo and Matias-Clavero (2019) used UTAUT model in their study carried out in Spain, and found that performance expectancy and facilitating conditions parameters have a significant role in the use of cryptocurrency.

In conclusion, previous studies indicate that it is possible to research the tendencies to own cryptocurrencies, which bring technology and economy together on a common ground, from the perspective of TAM.

\section{Problem \& Aim}

The problem, which the study addresses, is based on three important pillars. Based on the literature, it can be argued that studies conducted in Turkey contribute to the use of cryptocurrencies in macro context. Cryptocurrencies were discussed as an economic phenomenon or from the perspective of industry. Although factors which drive individuals to own cryptocurrencies or characteristics of cryptocurrency owners have a direct influence on cryptocurrency using 
industries or cryptocurrencies as an economic phenomenon, these parameters are still an unexplored domain in Turkey. In this sense, study expands the boundaries of knowledge in terms of cryptocurrency ownership in Turkey with its micro-level approach and it concentrates on motivations behind individuals' cryptocurrency ownership decisions in a country, which has a potential in terms of use of cryptocurrency.

On the other hand, in general, there are limited number of studies that shed light on factors which drive individuals to own cryptocurrencies. In addition, existing literature is mostly designed in a country-specific manner or studies mainly focus on a specific geographical area (e.g. European Union). Thus, conducting a study in local scale that explores the driving factors of cryptocurrency ownership in Turkey is vital for closing the knowledge gap, understanding the current situation and contributing in further studies.

Lastly, the amount of information about the influence of technology adoption pattern and speed on individuals' cryptocurrency ownership decision is limited. Previous studies do not contain any categorisation on the speed or pattern of technology adoption of individuals. However, these parameters are of capital important with regard to the decision to own cryptocurrencies and reasons behind cryptocurrency ownership. This study produces new knowledge to understand the relationship between intellectual capital on technology and cryptocurrency ownership by integrating Rogers (1983) and Moore's (1991) categorisation in to the metrics.

As explained in literature section, the attitudes developed by individuals with regard to accepting a technology differs, and it is obvious that these attitudes are influenced by several different parameters. While some users are sceptical and their tendencies are need oriented, others consider ownership as the primary goal and they are open to innovation. On the other hand, it was observed that when individuals accept a new technology, they are influenced by performance expectancy, effort expectancy, their social environment and the anxiety they feel when they use the technology. This can be observed both in the acceptance of many technologies and the use of cryptocurrencies

Within the framework of the study, Roger and Moore's technology adopter categorization, UTAUT2 model developed by Venkatesh et. al. based on Davis, and early researches carried in countries outside Turkey about the use of cryptocurrency were addressed and their relation with the use of cryptocurrency was investigated. It was also aimed to understand individuals' decision to use cryptocurrency in a multi-dimensional manner by establishing a relationship between technology adopter categorizations and UTAUT2 model, and develop a cryptocurrency adopter categorization as a result of the study by also using UTAUT2's parameters. In the context of this aim and literature background, two research questions were developed.
RQ1. How is cryptocurrency use intention influenced by technology acceptance parameters?

RQ2. What are the parameters considered by individuals, who belong to different technology adapter categories, in decision to use cryptocurrency?

In addition to two main research questions presented above, one of the aims of the study is to make a contribution to the field by developing a cryptocurrency ownership categorisation in the conclusion section similar to technology adopter categorization. Outputs of two main research questions mentioned above was considered in order to develop this categorisation and present the features of the categorisation.

\section{Methodological Approach}

This study, which aims to reveal the relationship between the parameters determined within the theoretical framework and decision to have cryptocurrency, adopts analytic research perspective. The questionnaire was used as an instrument to collect data necessary for coming up with the answers to the research questions. Opinions of Rowley (2014) was adopted for the designing and circulation of questionnaire.

The questionnaire was circulated in both printed format and electronic media since technological literacy levels of individuals in different age groups were taken into account. Within the scope of the questionnaire, 20 closed ended questions were asked to participants by taking the theoretical ground into account. The questionnaire include questions intended for determining the educational level, age and gender of the selected sample, statements aiming to understand technology adopter categorization, and statements intended for understanding the role of technology acceptance model's variants, namely, performance expectancy, effort expectancy, social influence, facilitating conditions and anxiety on the ownership of cryptocurrency. These parameters are important to shed light on driving factors of cryptocurrency ownership. Questions are presented with 5 different answer options from Strongly Agree to Strongly Disagree. In the questionnaire, SPSS 25 software was used for measuring the reliability of statements related to performance expectancy, effort expectancy, social influence, facilitating conditions and anxiety, and Cronbach's alpha value was found. As a result of the test, it was observed that Cronbach's Alpha value of above-mentioned metrics is ,753. It can be suggested that statements, which were tested based on George \& Mallery's (2016, p. 240) Cronbach's Alpha output evaluation metrics have a good internal consistency. 


\begin{tabular}{|c|c|}
\hline Statements About the Use & Theoretical Ground \\
\hline $\begin{array}{l}\text { Adopter Categorization } \\
\text { - My attitude towards technology is not need oriented. My } \\
\text { primary goal is to have it. } \\
\text { - I own technology not for trying, but for the purpose of } \\
\text { making use of it. } \\
\text { - I do not take risks when owning a technology is in question, } \\
\text { and prefer only approved and generally accepted products. } \\
\text { - I am sceptical towards technology. I do not seek anything } \\
\text { new until I have problems in technological platforms / devices I } \\
\text { am currently using. } \\
\text { - My bond with old technological devices/platforms prevent } \\
\text { me from tending towards new technologies. }\end{array}$ & Rogers (1983), Moore (1991) \\
\hline $\begin{array}{l}\text { Intention to Use } \\
\text { - I own cryptocurrencies / I owned them in the past. } \\
\text { - I have never owned cryptocurrencies. } \\
\text { - I am planning to own cryptocurrencies in future. }\end{array}$ & $\begin{array}{l}\text { TAM2 (Venkatesh \& Davis, 2000), Arias-Oliva, } \\
\text { Pelegrín-Borondo \& Matias-Clavero, } 2019\end{array}$ \\
\hline $\begin{array}{l}\text { Performance Expectancy } \\
\text { - Using cryptocurrencies increased my opportunities to } \\
\text { achieve- important goals of mine. } \\
\text { - Using cryptocurrencies help me achieve my goals faster. } \\
\text { - Using cryptocurrencies improves my life standards. }\end{array}$ & $\begin{array}{l}\text { UTAUT (Venkatesh et. al.,2003), UTAUT2 } \\
\text { (Venkatesh, Thong \& Xu, 2013), Arias-Oliva, } \\
\text { Pelegrín-Borondo \& Matias-Clavero, } 2019\end{array}$ \\
\hline $\begin{array}{l}\text { Effort Expectancy } \\
\text { - It is easy to learn how to use cryptocurrency. } \\
\text { - Use of cryptocurrency is clear and understandable. } \\
\text { - It is easy to be a sophisticated cryptocurrency user. }\end{array}$ & $\begin{array}{l}\text { UTAUT (Venkatesh et. al.,2003), UTAUT2 } \\
\text { (Venkatesh, Thong \& Xu, 2013), Arias-Oliva, } \\
\text { Pelegrín-Borondo \& Matias-Clavero, } 2019\end{array}$ \\
\hline $\begin{array}{l}\text { Social Influence } \\
\text { - Opinions of persons, who are important to me, are } \\
\text { important for my decision to use cryptocurrency. } \\
\text { - Opinions of people, who have an influence on me, are } \\
\text { important for my decision to use cryptocurrency. } \\
\text { - Opinions people, whose ideas I value, are important for my } \\
\text { decision to use cryptocurrency. }\end{array}$ & $\begin{array}{l}\text { UTAUT (Venkatesh et. al.,2003), UTAUT2 } \\
\text { (Venkatesh, Thong \& Xu, 2013), Arias-Oliva, } \\
\text { Pelegrín-Borondo \& Matias-Clavero, } 2019\end{array}$ \\
\hline $\begin{array}{l}\text { Facilitating Conditions } \\
\text { - I have the resources necessary for using cryptocurrency. } \\
\text { - I have the background information necessary for using } \\
\text { cryptocurrency. } \\
\text { - Cryptocurrencies are compatible with other technological }\end{array}$ & $\begin{array}{l}\text { UTAUT (Venkatesh et. al.,2003), UTAUT2 } \\
\text { (Venkatesh, Thong \& Xu, 2013), Arias-Oliva, } \\
\text { Pelegrín-Borondo \& Matias-Clavero, } 2019\end{array}$ \\
\hline
\end{tabular}


platforms I am currently using.

- I can get help when I have difficulty in using cryptocurrency.

\section{Anxiety}

- I find the idea of using cryptocurrency worrisome.

- I am afraid that I might suffer a loss by making a wrong transaction while using cryptocurrency.

\section{Table 2: Questionnaire Variants and Theoretical Ground}

Data collected with the questionnaire was analysed with data mining in order to define factors which drive individuals to own and use cryptocurrencies. In addition, a descriptive perspective was adopted in order to understand the relationship between individuals' decision to use cryptocurrency and technology adopter categorizations. Data mining can be defined as a technique which is suitable for the nature of technology acceptance studies. Because it enables researchers to elicit latent patterns that exist in data set. Within the framework of the study, a multidimensional illustration of factors and its influence on cryptocurrency use can be achieved through data mining approach.

As one of the data mining tools, decision tree algorithm was established for answering the first research question. According to Fenn (2015) "Decision trees are tools that showcase 'decisions' and their possible outcomes." In addition, according to Murthy (1998), "[Decision trees can be used] in order to reduce a volume of data by transforming it into a more compact form which preserves the essential characteristics and provides an accurate summary." Considering the Fenn's and Murthy's propositions, it is possible to reach valuable insights by analyzing this study's data via decision trees since the main motivation of the study is to explore the influence of technology acceptance parameters on decision of cryptocurrency use.

Thus, a decision tree algorithm was established by means of Rapidminer Studio 9.2.001 software and information_gain criterion was used in this algorithm for obtaining maximum information. Rapidminer Documentation platform described information_gain criterion as follows:

"The entropies of all the Attributes are calculated and the one with least entropy is selected for split. This method has a bias towards selecting Attributes with a large number of values."

In this context, establishing a decision tree algorithm, which includes information_gain criterion, complies with analytical research perspective, and plays an important role in obtaining refractions among statements with the least entropy value and explaining factors that influence the use of cryptocurrency. In

2 It is necessary to note that researchers considered profile diversity while choosing sample. Sample surveyed is not statistically representative of the population of Turkey. addition to this, since questionnaire form includes only 20 variants in total, the possibility of finding bias in the selection of break points decreases. Therefore, using information gain criterion in decision tree algorithm is suitable for obtaining accurate results.

Decision trees and descriptive statistics were used for answering the second research question. Because it is aimed to explore relationship between technology adopter categorizations specified by the participants, cryptocurrency use intention to use selections and technology acceptance parameters.

1. The answers given were first filtered according to technology adopter categorisation.

2. Cryptocurrency ownership status was determined for each category.

3. Influencing parameters in each technology adopter category were explored with decision trees. Because of low number of individuals defined themselves as Late Majority and Laggards, decision trees and descriptive statistics were used together to obtain better insights for these two categories.

Cryptocurrency adopter categorisations were created by using the outputs of the questions and the theoretical ground created by technology adopter categorisation.

\section{Population and Sample}

Since the research aims to understand important factors that play a role in the cryptocurrency ownership of individuals living in Turkey, research sample consists of individuals between the ages 20-59, who live in Turkey $^{2}$. GPower 3.1.9.4 software was used for calculating the sample size, and calculation was performed by using matched pairs t-test by means of the program $^{3}$. The calculation indicated that the necessary sample size is $381^{4}$. Individuals at a wide age range were included to the sample in order to increase sample's chances of representing the universe. Different age groups were included to the sample by considering the fact that cryptocurrency ownership is a subject, which is related to the use of technology and the ability to make economic decisions. In this context, it was ensured that

${ }^{3}$ Two tailed, effect size 0.2 , a error probability 0.025 , power 0.95

${ }^{4}$ Different online tools also indicated the same sample size values. 
age groups with different technological literacy levels and different economic profiles were represented. As an example, it is probable that an individual at the age of 20 is a student/scholarship holder, an individual, who is 30 years old is an active worker, and an individual aged 59 is retired. On the other hand, it is possible that technology usage habits of an individual aged 20 and an individual aged 59 are different.

Instant messaging groups, social discussion platforms, social media channels, cryptocurrency groups founded on social media channels, where discussions are held on cryptocurrency, were used for participation in questionnaire, which was circulated in digital platforms. Also, the questionnaire was shared with the user list of a cryptocurrency stock markets with an announcement, and the questionnaire link and via social media accounts of the followers of a cryptocurrency news website. Printed questionnaire was conducted mostly in İstanbul since it is Turkey's one of the most important economic centers, where different profiles of people live as a result of migration from different cities of the country.

\section{Findings}

407 persons participated in the questionnaire, which was open to participation between the dates 15.04.2019 - 22.05.2019. However, 22 questionnaires were eliminated and 385 questionnaires were evaluated in the analysis phase due reasons such as not being in the age range of the questionnaire sample, stating the birth year wrong, or leaving this field empty ${ }^{5}$. This sample size is suitable for specified sample size required for conducting the study, and shows quite a diversity in terms of age range. Following findings were obtained for the demographic features of participants.

\begin{tabular}{|c|c|c|}
\hline Age Ranges & Percentage in Sample Size & Number of Participants in the Questionnaire \\
\hline $\mathbf{2 0 - 2 4}$ & $\% 17.7$ & 68 \\
\hline $\mathbf{2 5 - 2 9}$ & $23.4 \%$ & 83 \\
\hline $\mathbf{3 0 - 3 4}$ & $21.6 \%$ & 62 \\
\hline $\mathbf{3 5 - 3 9}$ & $16.1 \%$ & 34 \\
\hline $\mathbf{4 0 - 4 4}$ & $8.8 \%$ & 15 \\
\hline $\mathbf{4 5 - 4 9}$ & $3.9 \%$ & 18 \\
\hline $\mathbf{5 0 - 5 4}$ & $4.7 \%$ & 15 \\
\hline $\mathbf{5 5 - 5 9}$ & $3.9 \%$ & \\
\hline
\end{tabular}

Table 3: Questionnaire participants according to age ranges

$49 \%$ of the participants are women, $51 \%$ of participants are men. Distribution of participants in age/gender segment is given in the table below.

\begin{tabular}{|c|c|c|}
\hline Age Ranges & Female & Male \\
\hline $\mathbf{2 0 - 2 4}$ & 35 & 53 \\
\hline $\mathbf{2 5 - 2 9}$ & 34 & 53 \\
\hline $\mathbf{3 0 - 3 4}$ & 30 & 42 \\
\hline $\mathbf{3 5 - 3 9}$ & 20 & 18 \\
\hline $\mathbf{4 0 - 4 4}$ & 16 & 12 \\
\hline $\mathbf{4 5 - 4 9}$ & 8 & 8 \\
\hline $\mathbf{5 0 - 5 4}$ & 6 & 7 \\
\hline
\end{tabular}

Table 4: Questionnaire participants according to age ranges and gender

It is observed that $6 \%$ of the participants are primary school graduates, 25\%of participants are high school graduates, $45 \%$ of the participants have undergraduate degree, $17 \%$ of the participants have graduate degree, and $7 \%$ of participants have doctorate degree.

\footnotetext{
${ }^{5}$ E.g. 2019 was written in birth year.
} 


\begin{tabular}{|c|c|c|c|c|c|}
\hline Age Ranges & $\begin{array}{l}\text { Primary } \\
\text { School }\end{array}$ & High School & $\begin{array}{c}\text { Undergraduate } \\
\text { Degree }\end{array}$ & Graduate Degree & Doctorate \\
\hline $20-24$ & 0 & 37 & 30 & 1 & 0 \\
\hline $25-29$ & 0 & 10 & 57 & 18 & 5 \\
\hline $30-34$ & 3 & 7 & 40 & 26 & 7 \\
\hline $35-39$ & 3 & 19 & 22 & 11 & 7 \\
\hline $40-44$ & 5 & 11 & 11 & 3 & 4 \\
\hline $45-49$ & 3 & 5 & 3 & 3 & 1 \\
\hline $50-54$ & 7 & 4 & 4 & 1 & 2 \\
\hline 55-59 & 1 & 5 & 5 & 3 & 1 \\
\hline
\end{tabular}

Table 5: Questionnaire participants according to age ranges and educational status

It was determined that $29 \%$ of participants currently have cryptocurrencies or had cryptocurrencies in the past, $12 \%$ of participants plan to use cryptocurrencies in future, and $59 \%$ of participants have never used cryptocurrencies.

\begin{tabular}{|c|c|c|c|}
\hline Age Ranges & Owns it (or had it in the past) & Plans to use in future & Never owned \\
\hline $\mathbf{2 0 - 2 4}$ & 15 & 13 & 40 \\
\hline $\mathbf{2 5 - 2 9}$ & 26 & 15 & 43 \\
\hline $\mathbf{3 0 - 3 4}$ & 33 & 3 & 34 \\
\hline $\mathbf{3 5 - 3 9}$ & 25 & 5 & 19 \\
\hline $\mathbf{4 0 - 4 4}$ & 10 & 1 & 14 \\
\hline $\mathbf{4 5 - 4 9}$ & 0 & 0 & 17 \\
\hline $\mathbf{5 0 - 5 4}$ & 1 & 1 & 13 \\
\hline $\mathbf{5 5 - 5 9}$ & 1 & 3 & \\
\hline
\end{tabular}

Table 6: Questionnaire participants according to age ranges and cryptocurrency usage status

$R Q 1$. How is cryptocurrency use intention influenced by technology acceptance parameters?

Findings on the first research question, which aims to understand how cryptocurrency use intention is influenced by technology acceptance parameters, were obtained with $75.83 \%$ accuracy.

Results presented in decision tree algorithm indicate that agreement level on the statement "'Using cryptocurrency increases my opportunities to achieve important goals of mine", which is one of the technology acceptance parameters, has an influence on cryptocurrency intention to use. Accordingly, performance expectancy variant is the most determinant on the attitude towards cryptocurrency use. It is observed that persons who give the answer 'strongly agree' to the statement "Using cryptocurrency increases my opportunities to achieve important goals of mine" own cryptocurrencies, and persons who have the answers 'strongly disagree' and 'disagree' have never had cryptocurrencies.

Results presented in decision tree indicate that the parameter which influences the usage intention of participants who gave the answer 'agree' - as a milder level of agreement - to the statement "Using cryptocurrency increases my opportunities to achieve important goals of mine" is the variant "I have the resources necessary for using cryptocurrency." It is observed that persons who chose strongly agree and agree options for this statement currently own cryptocurrencies or had cryptocurrencies in the past. It is observed that persons who do not have an opinion about or strongly disagree with this statement do not own cryptocurrencies. Accordingly, facilitating conditions can be considered as the second important factor for cryptocurrency use.

Finally, it is observed that participants who chose the 'I have no idea' option to the statement "Using cryptocurrency increases my opportunities to achieve important goals of mine" tend not to have cryptocurrencies.

As far as the current findings on the first research question is considered, it can be suggested that performance expectancy and facilitating conditions are the most important factors for the decision to use cryptocurrency among surveyed sample in Turkey. 
RQ2. What are the parameters considered by individuals, who belong to different technology adopter categories, in decision to use cryptocurrency?
After the filtering and averaging steps, the following table, which describes the relationship between technology adopter categorization parameters, technology acceptance parameters and cryptocurrency ownership, was developed.

\begin{tabular}{|c|c|c|c|}
\hline $\begin{array}{c}\text { Technology Adopter } \\
\text { Categorization }\end{array}$ & $\begin{array}{c}\text { Owns it (or had it in the } \\
\text { past) }\end{array}$ & Plans to use in future & Never owned \\
\hline Innovators & $62 \%$ & $24 \%$ & $14 \%$ \\
\hline Early Adopters & $29 \%$ & $13 \%$ & $49 \%$ \\
\hline Early Majority & $16 \%$ & $85 \%$ & $78 \%$ \\
\hline Late Majority & $14 \%$ & $0 \%$ & $100 \%$ \\
\hline Laggards & $0 \%$ & & $58 \%$ \\
\hline
\end{tabular}

Table 7: The relationship between technology adopter categories, cryptocurrency and TAM

$62 \%$ of Innovators own cryptocurrency. With this aspect, Innovators have the highest rate in cryptocurrency ownership category. Performance expectancy was determined as the most important factors that influence cryptocurrency ownership of Innovators. Decision tree illustrated the factors that affect the adaptation of cryptocurrencies by Innovators with $76.73 \%$ accuracy. Results indicate that Innovators consider how cryptocurrencies increase their opportunities to achieve important goals. Having necessary resources and regarding oneself as a sophisticated cryptocurrency can also be considered as secondary influencing factors that affect the cryptocurrency adoption decision of Innovators.

$29 \%$ of Early Adopters own cryptocurrency. The most important parameters of Early Adopters of cryptocurrency ownership was determined as facilitating conditions. Parameters that affect Early Adopters' cryptocurrency adoption was identified with $70.37 \%$ accuracy. The most important factor that has influence on cryptocurrency adoption decision of Early Adopters is their knowledge level on the issue. This finding supports that Early Adopters' attitude towards technology in general can be observed in terms of cryptocurrencies too. Within the context of cryptocurrency adoption, Early Adopters are slower compared to Innovators due to they need to build an intellectual capital before having cryptocurrencies.

$16 \%$ of participants in Early Majority category own cryptocurrencies. Decision tree produced results with $81.08 \%$ accuracy. Cryptocurrency ownership decision of participants included in this category is mainly influenced by performance expectancy however effort expectancy and anxiety can be defined as secondary influencing factors. If individuals who belong to Early Majority category strongly agree with the statement "Using cryptocurrencies increased my opportunities to achieve- important goals of mine," they are inclined to adopt it. Cryptocurrency usage of Early Majority was indirectly influenced by the extend to which find the ideas using crypto currencies worrisome or use of cryptocurrency is clear and understandable. Early Majority is the biggest participant group that plans using cryptocurrency in future.
$14 \%$ of participants who are included in Late Majority group stated that they own cryptocurrencies. Decision tree produced results with $66.67 \%$ accuracy. Descriptive analysis and decision trees were used together in order to explore influencing factors of cryptocurrency adoption among Late Majority since number of people who belong to this category and accuracy rate are relatively low. Anxiety parameter affect the cryptocurrency ownership decisions of users in this category. Individuals who define themselves as Late Majority indicate that they find the idea of using cryptocurrency worrisome. Late Majority is the biggest participant group along with Laggards, who have never owned cryptocurrencies.

None of the users, who state that they are in Laggards group, own cryptocurrencies. Because of small number of individuals exist in this category, a descriptive analysis applied. Results indicates that anxiety and facilitating conditions parameters that influence this group in cryptocurrency ownership decision.

\section{Discussion \& Conclusion}

While findings obtained present TAM parameters which influence the cryptocurrency ownership decisions of technology adopter categories, features of technology adopter categories suggested by Rogers and Moore indicate that there is a consistent pattern between TAM parameter and cryptocurrency ownership tendencies. For instance, while cryptocurrency ownership rate of innovators, who would like to have the technology first, is the highest, Laggards, who are the latest category in the process of adopting the technology, do not have cryptocurrencies, and while Innovators have the lowest anxiety level in terms of cryptocurrency use, Laggards have the highest anxiety level.

Results obtained from decision tree revealed that performance expectancy and facilitating conditions are the most influential factors in terms of cryptocurrency ownership in general. Arias-Oliva et. al., (2019) suggest that "the product and service design for a new cryptocurrency (or the innovation efforts for current ones) should focus on performance as the most critical adoption factor." Finding for the first research question makes this proposition usable also in context of Turkey. Because performance expectancy is the most influential factor of cryptocurrency use in Turkey, and individuals 
pay attention to how cryptocurrencies increase their opportunities to achieve important goals. This finding is a useful insight for cryptocurrency using industries since it is possible to suggest that they can reach more people by designing and marketing their services based on performance expectancy. On the other hand, Karaoğlan et. al., (2018) stated that owners of establishments, who accept cryptocurrencies as a mean of payment, aim to use advertising and publicity power of technology. Based on this proposition and our findings, it is possible to argue that both micro and meso level users of cryptocurrencies approach cryptocurrencies from the perspective of performance expectancy.

On the other hand, facilitating conditions are crucial in terms of cryptocurrency usage. Individuals indicate that in case they have the resources necessary, they are inclined to use cryptocurrencies. In this sense, it is possible to state that individuals do not perceive cryptocurrencies as money or an alternative to money but as an investment tool. Because, they tend to use it in case they have resources. Therefore, functional value proposition of a cryptocurrency becomes an important factor as far as its usage in Turkey is considered.

While the age average of participants in Innovators category is 30, age average of participants in Laggards category is 47 . As presented in Table 6 , while Innovators have the highest rate in cryptocurrency, Laggards have the lowest rate in this category. Under the light of this finding, it is possible to suggest that an age-oriented gap exists in cryptocurrency usage. Thus, industries, which aim to adopt cryptocurrencies as payment or investment method, should develop a perspective considering this gap in their service and product development

It was observed that Innovators category, who has the highest rate of cryptocurrency ownership rate with $62 \%$, are influenced by performance expectancy. In addition, facilitating conditions variants were considered as secondary factors when taking this decision. These results indicate that Innovators approach cryptocurrencies as a means to achieve their goals, and they decide to use it within the framework of the value it adds to their daily life. Also, another statement, On the other hand, in the context of facilitating conditions, whether they have the sources necessary for using cryptocurrency is taken account. As explained in the literature, these individuals included in the category of those who take quick action in the process of accepting an innovation, are also more reactive than other categories in terms of cryptocurrency ownership. Innovators focus on functional value of cryptocurrencies since they have been considering how cryptocurrencies increase their opportunities to achieve important goals. Innovators are pioneers in cryptocurrency adoption but they expect a long-term return from cryptocurrencies. In this sense, it is possible to interpret that cryptocurrencies which has a functional value proposition as an investment tool has higher chance to be adopted in the context of Turkey. In addition, Innovators are the first ones who gain knowledge on cryptocurrencies, since they are pioneers in technology adoption process. This situation makes them influencers and their thoughts on usage and ownership of cryptocurrencies matter in terms of perpetuation of this technology among others.
Early Adopters have the second highest rate in cryptocurrency ownership with 29\%. Facilitating conditions are important factors that influence the cryptocurrency ownership decision of Early Adopters. It is the technology adopter category which adopts a technology not for trying, but for the purpose of using it. Based on this, results validate this condition for cryptocurrency adoption. Within this framework, cryptocurrency adoption decision of Early Adopters is influenced by the channels, through which they obtain information. Frequency and quality of this information are other factors which affect gaining satisfactory amount of knowledge on cryptocurrencies. Another important parameter in this context is perceived reliability of information obtained from Innovators and strength of communication established with them. Because, as a result of blockchain technology, cryptocurrencies can function based on the trust established between two independent parties. In this sense, connection between Innovators, as a generation which has first-hand experience of the technology, and Early Adopters who need information to adopt cryptocurrencies. It can be argued that Early Adopters' and Innovators' tendency to use cryptocurrency is higher compared to remaining technology adopter categories. Starting from Early Majority anxiety becomes a dominant factor that affects the use of cryptocurrencies.

In this research, which was carried out in Turkey, Early Majority is ranked in the third place with $16 \%$ in the context of cryptocurrency ownership. Performance expectancy, effort expectancy and anxiety are the most important parameters that influence this category in terms of cryptocurrency ownership. In cryptocurrency ownership context, avoiding risks in technology acceptance process, which is one of the most distinct features of Early Majority. In this study, which was carried out in Turkey, one of the interesting findings on the Early Majority is the fact that individuals, who are planning to use cryptocurrency in future, are found in this category the most. If individuals who belong to Early Majority category believe that use of cryptocurrencies is clear and understandable, they are inclined to adopt cryptocurrencies. It is possible to provide arguments about the findings on Early Majority in two different domains. Firstly, effort expectancy and anxiety as secondary influencing factors show that Early Majority needs specific information on how to use cryptocurrencies in order to decrease their anxiety level for adopting cryptocurrencies. Secondly, it is possible to suggest that individuals in Early Majority category in Turkey might not have efficient channels to obtain information on cryptocurrencies. Because, Early Majority is the largest group who underlined that they plan to use cryptocurrencies in the future but they are at the third place as far as cryptocurrency ownership is concerned. This situation indicates that information flow that decrease the anxiety can transform potential users to active users. In this sense, they need the experience of Innovators and Early Adopters, and the information they will provide.

Late Majority, which is ranked in the fourth place in cryptocurrency ownership decision with $14 \%$, is influenced by anxiety variant. Based on the results, it is possible to state that cryptocurrency adoption pattern of Late Majority is more similar to Laggards than early Majority in Turkish context. Their sceptical approach and 
limited knowledge on technology can significantly be observed in terms of cryptocurrency ownership. When the functioning of the system of blockchain and attitude of Late Majority towards technology acceptance are taken into account, characteristics of cryptocurrencies can influence anxiety level significantly. Because they do not have a physical reality, they have a decentralized working system and they function based on the trust of two parties.

In this research, which was carried out in Turkey, Laggards are ranked in last place with $0 \%$ in the context of cryptocurrency ownership. The most important parameter, which influences cryptocurrency ownership of Laggards, is anxiety. Laggards clearly state that they have concerns about using cryptocurrency. This indicates that they consider the concept of cryptocurrency in general rather than having a fear of suffering an economic loss. In this regard, the concerns they have about integrating new technologies to their life, and their attachment to their previous technological habits also play an active role. Also, the fact that Laggards do not seek any innovation in their life and they only tend to use a new technology when they cannot use the current one is another factor that brings them to the last place in consumer acceptance category. Considering the possible economic risks that might result from the internal changes and market volatility of cryptocurrencies, which have advantages as well as disadvantages like all new technologies, it is observed that such factors influence users, who feel that they belong to Late Majority and Laggards group, negatively particularly in terms of consumer acceptance. In addition, operating mentality of cryptocurrencies does not overlap with their current economic payment or investment patterns.

Findings obtained as a result of the study indicate that cryptocurrency is adopted to the extent that in contributes to the achievement of life goals as evaluated in the context of performance expectancy, and facilitating conditions also play a role in this adoption process in Turkey. In this research, when the results obtained by establishing a connection between technology adopter categorization and technology acceptance model, is considered, it is observed that there are three different cryptocurrency adopter categories. These categories can be named as coin optimistics, observers and coinsceptics.

Coin-optimistics can be considered as pioneers, who approach to cryptocurrencies as a means to achieve their objectives, and do not have any anxiety about acting beyond their classical preferences in their technology usage decisions. They do not feel any reservations about cryptocurrency ownership when they have sufficient background information and sources required for cryptocurrency usage. Coin-optimistics also act as transmitters of information. This group, which integrate cryptocurrencies to their lives faster than others, influence the cryptocurrency ownership decisions of observers by sharing their experiences with them. In this context, coin-optimistics, who are the youngest group among other categorisations, play a key role in changing current lifestyles to help others adopt to the new advantages of the age.

Observers are a group of persons, who observe the use of cryptocurrency in their social environment and take a decision about whether or not owning cryptocurrencies according to the information they obtain from this environment. Although facilitating conditions is a parameter that influence cryptocurrency ownership decision of observers, their anxiety, which is not at high levels, direct them to take a decision according to the information they will obtain from their social environment. The experiences of coin-optimistics, who act as pioneers in the cryptocurrency ownership decisions, and the information they share are important factors for the observers. According to this flow of information, observers decide to own cryptocurrencies or join the category of coin-sceptics, who have a sceptical attitude towards cryptocurrencies,

Coin-sceptics approach cryptocurrency as a concept and owning cryptocurrencies with scepticism. As the last group that will take action for owning cryptocurrencies, coin-sceptics also have the highest age average. It can be suggested that the main reasons why coin-sceptics have a negative attitude towards cryptocurrency ownership are their attachment to previous habits, anxiety about suffering economic loss, and availability of more traditional alternatives for economic transactions and investments. Also use of social environment as the source of information and their technical literacy levels may also cause them to have anxieties about cryptocurrency ownership.

It is clear that cryptocurrencies are considered as the means to construct an individual centred economy by bringing technology and economy together as an innovation that emerged under the influence of technology, which has significant effects on social and economic status. Cryptocurrencies re-construct the economic perspectives inherent to daily life, and gains ground on the way to become a global medium of exchange, which is based on trust, technology and distributedness. As explained in cryptocurrency adopter categorizations above, adaptation of this peer-to-peer structured system, which eliminates especially physical existence of money, on an individual basis, takes place with different speeds and perspectives.

Finally, using technology acceptance model and technology adapter categorizations as a theoretical ground, this study determined the parameters that affect the individual adaptation of cryptocurrencies, and made an original contribution to the field by presenting cryptocurrency adopter categories. It is important that similar studies which focus on use of cryptocurrencies in micro perspective carried out in different countries. In this way, factors that affect the individual adaptation of cryptocurrencies will be understood thoroughly, and it will be possible to have comparative insights about how ownership profiles change.

\section{References}

Abroud, A., Choong, Y. V., Saravanan, M., Fie, D. Y. G. (2013). Adopting E-Finance: Decomposing the Technology Acceptance Model for Investors. Service Business, vol. 9(1), p. 161-182. DOI: $10.1007 / \mathrm{s} 11628-013-0214-\mathrm{x}$

Adams, D. A., Nelson, R. R., Todd, P. A. (1992). Perceived Usefulness, Ease of Use and Usage of Information Technology: A Replication. MIS Quarterly. vol. 16(2). p. 227-247. DOİ: $10.2307 / 249577$ 
Allam, Z. (2018). On Smart Contracts and Organisational Performance: A Review of Smart Contracts Through the Blockchain Technology. Review of Economic and Business Studies, vol. 11(2), p. 137-156. DOİ: 10.1515/rebs-2018-0079

Arbaugh, J. B. (2010). Multi-Disciplinary and ProgramLevel Research in Online Business Education. In Online and Blended Business Education for the 21st Century. p. 19-46. DOİ: 10.1016/B978-1-84334603-6.50002-3

Andone, I., Blaszkiewicz, K., Eibes, M., Trendafilov, B., Montag, C. \& Markowetz, A. (2016). How Age and Gender Affect Smartphone Usage. 2016 ACM International Joint Conference on Pervasive and Ubiquitous Computing. p. 9-12. DOİ: 10.1145/2968219.2971451

Antonopoulos, A. M. (2013). The Crypto-Currency Ecosystem: A Taxonomy of Alt-Coins, Meta-Coins and Blockchain-Riders.

<http:/ / radar.oreilly.com/2013/06/the-cryptocurrency-ecosystem.html> (Accessed 24 April 2019).

Antonopoulos, A. M. (2015). Mastering Bitcoin: Unlocking Digital Cryptocurrencies. USA: O’Reilly Media, Inc. ISBN 9781449374044

Arias-Oliva, M., Pelegrin-Borondo, J., Matias-Clavero, G. (2019). Variables Influencing Crypto-Currency Use: A Technology Acceptance Model in Spain. Frontiers in Psychology, DOİ: 10.3389/fpsyg.2019.00475

Banking Regulation and Supervision Agency. (2013). Access through Internet <https://www.bddk.org.tr/ContentBddk/dokuman /duyuru_0512_01.pdf> (Accessed 19 April 2019).

Banking Regulation and Supervision Agency. (2013). Access through Internet: <http:/ / www.mevzuat.gov.tr/MevzuatMetin/1.5.64 93.pdf $>$ (Accessed 19 April 2019).

Brynjolfsson, E., McAfee, A. (2014). The Second Machine Age. New York \& London: W. W. Norton \& Company.

Cao, Q., Niu, X. (2019). Integrating Context-Awareness and UTAUT To Explain Alipay User Adoption. International Journal of Industrial Ergonomics. vol. 69(1), p. 9-13. DOİ: 10.1016/j.ergon.2018.09.004

Christidis, K., Devetsikiotis, M. (2016). Blockchains And Smart Contracts for The Internet of Things. Institute of Electirical and Electronics Engineers Access, vol. 4, 2292-2303.

DOİ: 10.1109/ACCESS.2016.2566339

Chitungo, S. K., Munongo, S. (2013). Extending the Technology Acceptance Model to Mobile Banking Adoption in Rural Zimbabwe. Journal of Business Administration and Education, vol. (3)1, p. 51-79. $<$ https://infinitypress.info/index.php/jbae/article/ view/100/90>

Choi, K., Wang, Y., Sparks, B. (2019). Travel App Users' Continued Use Intentions: It's A Matter of Value and Trust. Journal of Travel \& Tourism Marketing, vol. 36(1), p. 131-143. DOİ: $10.1080 / 10548408.2018 .1505580$
Chuen, D. L. K. (2015). Handbook of Digital Currency: Bitcoin, Innovation, Financial Instruments, And Big Data. USA: Academic Press. ISBN 9780128021170

Davis, F. D. (1989). Perceived Usefulness, Perceived Ease of Use and User Acceptance of Information Technology. MIS Quarterly, vol. 13(3), p. 319-340. DOİ: $10.2307 / 249008$

Davis, F. D., Bagozzi, R. P., Warshaw, P. R. (1989). User Acceptance of Computer Technology: A Comparison of Two Theoretical Models. Management Science, vol. 35(8), p. 982-1003 <https://www.jstor.org/stable/2632151>

Davis, F. D., Bagozzi, R. P., Warshaw, P. R. (1992). Extrinsic and Intrinsic Motivation to Use Computers in The Workplace. Journal of Applied Social Psychology, vol. 22(14), p. 1111-1132. DOİ: 10.1111/j.1559-1816.1992.tb00945.x

Dizkırıc1, A. S., Gökgöz, A. (2018). Türkiye'de Kripto Para Birimleri Ve Türkiye'de Bitcoin Muhasebesi. Journal of Accounting, Finance and Auditing Studies, vol. 4(2), p. 92-105.

European Commission. (2015). Access through Internet:<http://publications.jrc.ec.europa.eu/repo sitory/bitstream/JRC97043/the\%20digital\%20age nda\%20of\%20virtual\%20currencies_final.pdf> (Accessed 1 May 2019).

European Central Bank. (2018). Access through Internet:<https://www.ecb.europa.eu/press/key/d ate/2018/html/ecb.sp180208.en.html> (Accessed 3 May 2019).

European Central Bank. (2015). Access through Internet:<https://www.ecb.europa.eu/pub/pdf/oth er/virtualcurrencyschemesen.pdf $>$ (Accessed 3 May 2019).

Fenn, L. (2015). Decision Trees and Surveys. Technical Report Hunter College. <http://larryfenn.com/decisiontrees.pdf>

Financial Action Task Force. (2014). Access through Internet:<http://www.fatfgafi.org/media/fatf/documents/reports/Virtualcurrency-key-definitions-and-potential-aml-cftrisks.pdf> (Accessed 1 May 2019).

Folkinshteyn, D., Lennon, M. (2017). Braving Bitcoin: A Technology Acceptance Model (TAM) Analysis. Journal of Information Technology Case and Application Research, vol. (18)4, p. 220-249. DOİ: $10.1080 / 15228053.2016 .1275242$

Gandal, N., Halaburda, H. (2014). Competition in The Crypto-Currency Market. Bank of Canada Working Paper, vol. 33, p. 1-33. <https://www.bankofcanada.ca/2014/08/working -paper-2014-33/>

George, D., Mallery, P. (2016). IBM SPSS Statistics 23 Step by Step: A Simple Guide and Reference. NY: Routledge. 
Gültekin, Y. (2017). Crypto-Currencies as An Alternative Medium of Payment in Tourism Industry: Bitcoin. Güncel Turizm Araştırmaları Dergisi. vol. 1(2), p. 96113.

https://dergipark.org.tr/guntad/issue/33598/279 729

Gültekin, Y., Bulut, Y. (2016). Bitcoin Ekonomisi: Bitcoin Ekosisteminden Doğan Yeni Sektörler Ve Analizi. Adnan Menderes Üniversitesi, Sosyal Bilimler Enstitüsü Dergisi, vol. 3(3). p. 82-92. https://dergipark.org.tr/tr/pub/adusobed/issue/2 $7378 / 288167$

Halassi, S., Semejin, J., Kiratli, N. (2019). From Consumer to Prosumer: A Supply Chain Revolution In 3D Printing. International Journal of Physical Distribution \& Logistics Management. vol. 49(2), p. 200-216. DOİ: 10.1108/IJPDLM-03-2018-0139

Herrero, Á., Martín, H. Garcia-de Los Salmones, M. (2017). Explaining the Adoption of Social Networks Sites for Sharing User-Generated Content: A Revision of The UTAUT2. Computers in Human Behavior, vol. 76, p. 209-217. DOI: 10.1016/j.chb.2017.02.007

Igbaria, M., Iivari, J., Maragahh, H. (1995). Why Do Individuals Use Computer Technology? A Finnish Case Study. Information \& Management, vol. 29(5), p. 227-238. DOİ: 10.1016/0378-7206(95)00031-0

Igbaria, M., Zinatelli, N., Cragg, P., Cavaye, A. L. M. (1997). Personal Computing Acceptance Factors in Small Firms: A Structural Equation Model. MIS Quarterly, vol. 21(3), p. 279-305. DOİ: $10.2307 / 249498$

Ingham, J., Cadieux, J., Berrada, A. M. (2015). EShopping Acceptance: A Qualitative and MetaAnalytic Review. Information \& Management. vol. 52(1), p. 44-60. DOİ: 10.1016/j.im.2014.10.002

Jackson, C. M., Chow, S., Leitch, R. A. (2007). Toward an Understanding of The Behavioral Intention to Use an Information System. Decision Sciences, vol. 28(2), p. 357-389. 5915.1997.tb01315.x

Kamac1, A., Özden, N. M. (2019). Lale Ç1lgınlığ Ve Kripto Para Ilişkisi. Econder International Economic Journal, vol. 3(1), p. 26-40. DOİ: 10.35342/econder.543363

Karaoğlan, S., Arar, T., Bilgin, O. (2018). Türkiye'de Kripto Para Farkındalığı Ve Kripto Para Kabul Eden Işletmelerin Motivasyonları. İşletme ve İktisat Çalışmaları Dergisi, vol. 6(2). p. 15-28. https://www.researchgate.net/publication/325206 619

Lawson-Body, A., Willoughby, L., Lawson-Body, L., Tamandja, E. M. (2018). Students' Acceptance of EBooks: An Application Of UTAUT. Journal of Computer Information Systems, p. 1-12. DOİ: 10.1080/08874417.2018.1463577
Liébana-Cabanillas, F., Muñoz-Leiva, F., SánchezFernández, J. (2017). A Global Approach to The Analysis of User Behavior In Mobile Payment Systems in The New Electronic Environment. Service Business, vol. 12(1), p. 25-64. DOİ: $10.1007 / \mathrm{s} 11628-017-0336-7$

Liu, D., Liu, A., Tu, W. (2019). The Acceptance Behavior Of New Media Entertainment Among Older Adults: Living Arrangement as A Mediator. The International Journal of Aging and Human Development, vol. 0(0), p. 1-25. DOİ: 10.1177/0091415019864602

Moore, G. A. (1991). Crossing the Chasm: Marketing and Selling High-Tech Products to Mainstream Customers. NY: Harper Collins. ISBN 0060189878

Morosan, C., DeFranco, A. (2016). It's About Time: Revisiting UTAUT2 To Examine Consumers' Intentions to Use NFC Mobile Payments in Hotels. International Journal of Hospitality Management, vol. 53, p. 17-29. DOİ: 10.1016/j.ijhm.2015.11.003

Morris, M. G., Dillon, A. (1997). How User Perceptions Influence Software Use. Institute of Electrical and Electronics Engineers Software, vol. 14(4), p. 58-65. DOİ: $10.1109 / 52.595956$

Murthy, S. K. (1998). Automatic Construction of Decision Trees from Data: A Multi-Disciplinary Survey. Data Mining and Knowledge Discovery, vol. 2(4), p. 345389. DOİ: $10.1023 / \mathrm{A}: 1009744630224$

Nakamoto, S. (2008). Bitcoin A Peer-To-Peer Electronic Cash System. <https://bitcoin.org/bitcoin.pdf> (Accessed 14 April 2019).

Naranjo-Zolotov, M., Oliveira, T., Casteleyn, S. (2019). Citizens' Intention to Use and Recommend EParticipation: Drawing Upon UTAUT And Citizen Empowerment. Information, Technology and People, vol. 32(2), p. 364-386. DOİ: 10.1108/ITP-08-20170257

Nordhoff, S., Winter, J., Kyriakidis, M., Arem, B., Happee, R. (2018). Acceptance of Driverless Vehicles: Results from A Large Cross-National Questionnaire Study. Journal of Advanced Transportation, vol. 1, p. 1-22. DOİ: $10.1155 / 2018 / 5382192$

Oghuma, A. P., Libaque-Saenz, C. F., Wong, S. F., Chang, Y. (2016). An Expectation-Confirmation Model of Continuance Intention to Use Mobile Instant Messaging. Telematics and Informatics, vol. 33(1), p. 34-47. DOİ: $10.1016 /$ j.tele.2015.05.006

Oliveira, T., Thomas, M., Baptista, G., Campos, F. (2016). Mobile Payment: Understanding the Determinants of Customer Adoption and Intention to Recommend the Technology. Computers in Human Behavior, vol. 61, p. 404-414. DOİ: 10.1016/j.chb.2016.03.030

Park, E., Kim, S., Kim, Y., Kwon, S. J. (2018). Smart Home Services as The Next Mainstream of The ICT Industry: Determinants of The Adoption of Smart Home Services. Universal Access in the Information Society, vol. 17(1), p. 175-190. DOİ: 10.1007/s10209-017-0533-0 
Patel, K. J., Patel, H. J. (2018). Adoption of Internet Banking Services in Gujarat: An Extension of TAM with Perceived Security and Social Influence, International Journal of Bank Marketing, vol. 36(1), p.147-169. DOİ: 10.1108/IJBM-08-2016-0104

Pavlou, P. A. (2014). Consumer Acceptance of Electronic Commerce: Integrating Trust and Risk with The Technology Acceptance Model. International Journal of Electronic Commerce, vol. 7(3), p. 101-134. DOİ: 10.1080/10864415.2003.11044275

Pilkington, M. (2016). Blockchain Technology: Principles and Applications. USA: Edward Elgar Publishing.

Plassaras, N. A. (2013). Regulating Digital Currencies: Bringing Bitcoin Within the Reach Of IMF. Chicago Journal of International Law, vol. 14(1), p. 377-407. https://chicagounbound.uchicago.edu/cjil/vol14/i ss $1 / 12 /$

Qin, L., Kim, Y., Hsu, J., Tan, X. (2011). The Effects of Social Influence on User Acceptance of Online Social Networks. International Journal of Human-Computer Interaction, vol. 27(9). p. 885-899. DOİ: $10.1080 / 10447318.2011 .555311$

Rogers, E. M. (1983). Diffusion of Innovations. New York: The Free Press. ISBN 0029266505

Rowley, J. (2014). Designing and Using Research Questionnaires. Management Research Review, vol. 37(3), p. 308-330. DOİ: 10.1108/MRR-02-20130027

Schlegel, M., Zavolokina, L., Schwabe, G. (2018). Blockchain Technologies From the Consumers' Perspective: What Is There and Why Should Who Care? Proceedings of the 51st Hawaii International Conference on System Sciences, p. 3447-3486. DOİ: 10.24251/HICSS.2018.441

Schwab, K. (2018). Dördüncü Sanayi Devrimi. İstanbul: Optimist Yayınları. ISBN 9786052181478

Shao, C., Kwon, K. H. (2019). Clicks Intended: An Integrated Model for Nuanced Social Feedback System Uses on Facebook. Telematics and Informatics, vol. 39, p.11-24. DOİ: $10.1016 /$ j.tele. 2018.12 .003

State of Wyoming. (2019). [accessed 12 April 2019]. Access through Internet: <https://www.wyoleg.gov/2019/Introduced/SF012 5.pdf $>$

Swan, M. (2015). Blockchain: Blueprint for A New Economy. Sebastopol, CA: O'Reilly Media, Inc. ISBN 9781491920497

Şahin, M. (2019). Kripto Para Yeni Bir Vergi Sığınağı Mi? Bilişim Teknolojilerindeki Gelişmeler Temelinde Bir Değerlendirme. Pamukkale University Journal of Social Sciences Institute, vol. 34, p. 169-181. DOİ: $10.30794 /$ pausbed.421510

Tavares, J., Goulão, A., Oliveira, T. (2017). Electronic Health Record Portals Adoption: Empirical Model Based On UTAUT2. Informatics for Health and Social Care, vol. 43(2), p. 109-125. DOİ: $10.1080 / 17538157.2017 .1363759$
Temelli, F. (2019). Kripto Para Birimlerinden Bitcoin Ve Muhasebe Açısından Değerlendirilmesi. İktisadi Yenilik Dergisi, vol. 6(2), p. 107-119. https://dergipark.org.tr/tr/pub/iy/issue/46636/5 66621

Venkatesh, V. (2000). Determinants of Perceived Ease of Use: Integrating Control, Intrinsic Motivation, And Emotion into The Technology Acceptance Model. Information Systems Research. vol. 11(4), p. 342365. DOİ: $10.1287 /$ isre.11.4.342.11872

Venkatesh, V., Davis, F. D. (2000). A Theoretical Extension of The Technology Acceptance Model: Four Longitudinal Field Studies. Management Science, vol. 46(2), p. 186-204. https://www.jstor.org/stable/2634758

Venkatesh, V., Morris, M. G., Davis, G. B., Davis, F. D. (2003). User Acceptance of Information Technology: Toward A Unified View. MIS Quarterly, vol. 27(3), p. 425-478. https://www.jstor.org/stable/30036540

Venkatesh, V., Thong, J., Xu, X. (2012). Consumer Acceptance and Use of Information Technology: Extending the Unified Theory of Acceptance and Use of Technology. MIS Quarterly, vol. 36(1), p. 157-178. http:/ / www.jstor.org/stable/41410412

Wallerstein, I. (1999). The End of The World as We Know It, Social Science for The Twenty-First Century. Minneapolis: University of Minnesota Press. ISBN 0816633975

Wu, M., Chou, H., Weng, Y., Huang, Y. (2011). TAM2Based Study of Website User Behaviour-Using Web 2.0 Websites as An Example. Wseas Transactions on Business and Economics, vol. 8(4), p. 133-151. http://www.wseas.us/elibrary/transactions/economics/2011/53-665.pdf

Yang, H. H., Feng, L., MacLeod, J. (2018). Understanding College Students' Acceptance of Cloud Classrooms in Flipped Instruction: Integrating UTAUT And Connected Classroom Climate. Journal of Educational Computing Research. vol. 56(8), p. 1258-1276. DOİ: $10.1177 / 0735633117746084$ 